\title{
Identification of equine herpesvirus 8 in donkey abortion: a case report
}

\author{
Tongtong Wang ${ }^{1 \dagger}$, Leyu Hư ${ }^{2 \dagger}$, Yonghui Wang ${ }^{1}$, Wenqiang Liu' ${ }^{1}$ Guiqin Liu', Mingxia Zhu' ${ }^{1}$, Wei Zhang ${ }^{3}$, \\ Changfa Wang ${ }^{1 *}$, Huiying Ren ${ }^{2^{*}}$ and Liangliang $\mathrm{Li}^{1^{*}} \mathbb{B}$
}

\begin{abstract}
Background: Equine herpesvirus-8 (EHV-8) is one of the most economically significant viruses that infect mammals of the genus Equus worldwide, which cause severe respiratory diseases and abortion in horses. However, there is no report of abortion caused by EHV-8 in donkeys.
\end{abstract}

Case presentation: The present case report is about a 4-year-old donkey having an abortion and showing a serious respiratory issue on the 296th day of pregnancy. Bacteriological and molecular tests were used to screen possible bacterial/viral pathogens to detect the etiological agent. Salmonella abortus equi, EHV-1, EHV-4, and EAV were all negative in the current study. EHV-8, on the other hand, was the only agent that was isolated and identified.

Conclusions: This was for the first time that EHV-8 had been isolated from a donkey in China. EHV-8 infection can cause abortion in donkeys; therefore, veterinarians and breeders should be aware of it.

Keywords: Donkey, Abortion, Equid herpesviruses 8, Virus isolation

\section{Background}

The primary infectious pathogens affecting the horse or donkey industries are equine herpesviruses (EHVs) [1]. Nine herpesviruses have been found in equids so far. EHV-1, EHV-2, EHV-3, EHV-4, and EHV-5 infect the horse, while EHV-6 (asinine herpesvirus, AHV-1), EHV-7 (AHV-2), and EHV-8 (AHV-3) are associated with infections in donkeys [2-4]. AHVs, EHV-8, and EHV-9, in particular, are more closely linked to EHV-1 than EHV-4 $[5,6]$.

EHV-8 is a Herpesviridae virus with a double-stranded enveloped DNA that belongs to the alphaherpesvirinae subfamily $[4,7]$. EHV-8's genome is around $150 \mathrm{~kb}$ long

*Correspondence: wangchangfa@lcu.edu.cn; renren0228@sina.com; lifeiyang2017@163.com

tTongtong Wang and Leyu Hu contributed equally to this work

${ }^{1}$ Research Institute of Donkey High-Efficiency Breeding and Ecological Feeding, College of Agronomy, Liaocheng University, Liaocheng, China

${ }^{2}$ College of Veterinary Medicine, Qingdao Agricultural University, Qingdao, China

Full list of author information is available at the end of the article and contains 76 open reading frames (ORFs) [8]. In 1988, EHV-8 was isolated in the nasal cavity of latently infected donkeys in Australia [3]. It was also identified from a horse with fever and nasal discharge in China and donkeys in Israel with severe post-castration incisional infection $[9,10]$. EHV-8's pathogenesis is unknown, and the virus has only been linked to respiratory and neurological illness in donkeys, as well as miscarriage in horses $[4,5]$.

Here is the first report documenting a typical case of EHV-8-induced abortion in a donkey. It has been proposed that EHV-8 is a potential pathogen linked to donkey abortion.

\section{Case presentation}

A 4-year-old female donkey from a large-scale farm in Liaocheng, China, had an abortion on the 296th day of pregnancy on May 29, 2021. Anorexia, sadness, unwillingness to move, and a bent head were all symptoms of the female donkey. Except for the lungs, which had a blue/purple tinge, necropsy of the aborted fetus revealed no visible gross abnormalities (Fig. 1). original author(s) and the source, provide a link to the Creative Commons licence, and indicate if changes were made. The images or other third party material in this article are included in the article's Creative Commons licence, unless indicated otherwise in a credit line to the material. If material is not included in the article's Creative Commons licence and your intended use is not permitted by statutory regulation or exceeds the permitted use, you will need to obtain permission directly from the copyright holder. To view a copy of this licence, visit http://creativecommons.org/licenses/by/4.0/. The Creative Commons Public Domain Dedication waiver (http://creativeco mmons.org/publicdomain/zero/1.0/) applies to the data made available in this article, unless otherwise stated in a credit line to the data. 

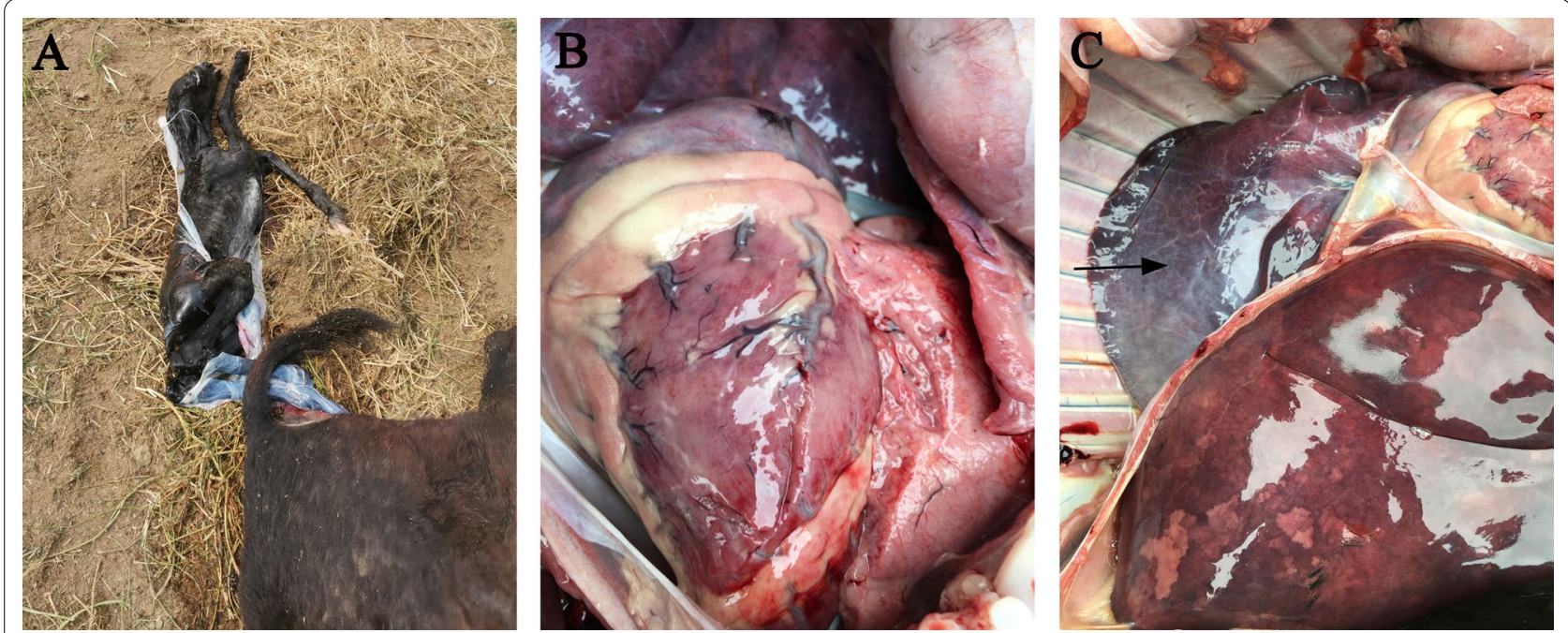

Fig. 1 Gross lesions of an aborted fetus. a Aborted fetuses of donkey; b Heart; c Lungs and liver

Table 1 The primer sequences in this study

\begin{tabular}{lll}
\hline Primers & Primer sequences $\left(\mathbf{5}^{\prime} \mathbf{- 3}^{\prime} \mathbf{)}\right.$ & $\begin{array}{l}\text { PCR } \\
\text { product } \\
\text { sizes } \mathbf{( b p )}\end{array}$ \\
\hline EAV ORF7-F & ATGGCGTCAAGACGATCAC & 333 \\
EAV ORF7-R & TTACGGCCCTGCTGGAGGC \\
EHV-1 gB-F & GAACCTCAGCCAACCCA & 792 \\
EHV-1gB-R & GCACTTTGCGGACGAAC & \\
EHV-4 gB-F & CTTAATCGCATTTAGACCGATG & 1591 \\
EHV-4 gB-R & CCGGAACTAGAAAGATGTTATGC \\
EHV-8 G1-F & TCAGACTGTCACTCGTGGGA & 316 \\
EHV-8 G1-R & CCTGGAGGCCGTTTAACACA & \\
\hline
\end{tabular}

The tissue specimens of the placenta, umbilical cord, lungs, and liver from the aborted fetus were taken for bacteriological testing to identify the etiological agent. As previously described, all tissue specimens were cultivated on Salmonella-Shigella agar and 5\% sheep blood agar and incubated at $37^{\circ} \mathrm{C}$ for $24 \mathrm{~h} \mathrm{[11]}$. There were no bacterial colonies on the culture plates, according to the results. Following that, as stated in earlier publications, potential viruses were identified [12]. An EasyPure ${ }^{\circledR}$ Viral DNA/RNA Kit was used to extract RNA and DNA from the placenta, umbilical cord, lungs, and liver tissues (Beijing TransGen Biotech Co., Ltd., China), according to the manufacturer's instructions. A PrimeScript ${ }^{\mathrm{TM}}$ RT-PCR kit was used to perform One-Step reverse transcriptionpolymerase chain reaction (RT-PCR) amplification using appropriate primers for EAV detection (Takara Bio, Inc., Japan). PCR was used to test for EHV-1, EHV-4, and EHV-8 using specified primers (Table 1). The PCR cycle was as follows: $94{ }^{\circ} \mathrm{C}$ for $5 \mathrm{~min}$, followed by 30 cycles at
$94{ }^{\circ} \mathrm{C}$ for $30 \mathrm{~s}, 56{ }^{\circ} \mathrm{C}$ for $45 \mathrm{~s}, 72{ }^{\circ} \mathrm{C}$ for 1 min and with a final extension at $72{ }^{\circ} \mathrm{C}$ for $10 \mathrm{~min}$. EAV, EHV-1, and EHV-4 were all found to be negative in all of the tissue samples. The umbilical cord, placenta, and lung tissues were all EHV-8-positive with a predicted 316 bp product. However, no detection in the liver tissues and identified using an agarose gel (Fig. 2).

Immunohistochemistry (IHC) was used on the placenta and umbilical cord to confirm EHV-8 infection in vivo, as described before [13-15]. Briefly, The umbilical cord and placenta tissue were preserved in $10 \%$ formalin, embedded in paraffin wax, cut to $5 \mu \mathrm{m}$ using a microtome (Leica), and mounted on slides. The slides were treated with hydrogen peroxide to inhibit endogenous peroxidase. After overnight immunostaining with EHV-8-positive serum (our lab stocks), slides were rinsed in PBS, treated with horseradish peroxidase-conjugated rabbit anti-donkey IgG for $1 \mathrm{~h}$, stained with diaminobenzidine for $5 \mathrm{~min}$, rinsed in water, counterstained in Gill's hematoxylin for $30 \mathrm{~s}$, dehydrated, cleared, and placed on a coverslip. Negative controls were treated identically to positive controls without the antibody incubation to evaluate non-specific binding effects. Because of the presence of diaminobenzidine, EHV-8-positive cells in the umbilical cord and placenta looked brown, as shown in Fig. 3, but no EHV-8-positive cells were seen in the control slides.

Following that, the EHV-8 strain was isolated as described previously [16]. The cytopathic effect (CPE) was seen in RK-13 cells (right) and negative cells (left) after two days of inoculation with the supernatant from an EHV-8-positive placenta (Fig. 4a). In order to evaluate EHV-8 isolate, the immunofluorescence assay (IFA) were 

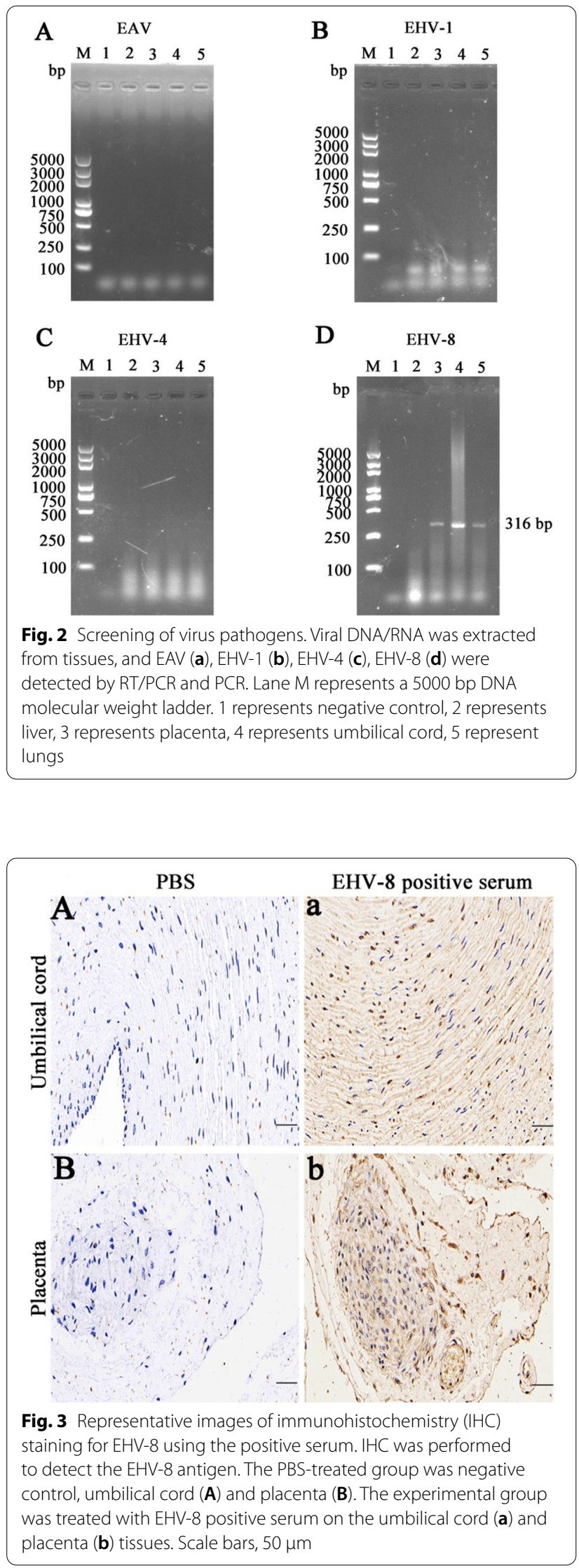

performed with anti-EHV-8 mouse serum (made in our lab), the CPE-positve cells and mock cells were fixed with 75\% alcohol repectively, a DyLight 594-labelled Goat Anti-Mouse $\operatorname{IgG}(\mathrm{H}+\mathrm{L})$ served as second antibody. Comparing with mock control RK-13 cells, EHV-8 proteins were observed in the cytoplasm and nucleus in CPE-positive cells (Fig. 4b).

Further, the EHV-8 isolate was then tested using PCR, the CPE-positive cells were collected, and DNA was extracted for EHV-8 detection using G1-Forward and G1-Reverse primers. In the CPE-positive group, an agarose gel electrophoresis revealed a single band with an anticipated size of $316 \mathrm{bp}$ (Fig. 4c).

Meanwhile, after a week of antibiotic treatment, the female donkey gradually recovered. The female donkey's nose swabs and blood samples were obtained and utilized to test for EHV-8 infection using PCR as described above. However, the ORF70 gene's incomplete sequence is still detectable in these samples (Additional file 1: Figure S1). Finally, the donkey was put down by the owner to prevent EHV-8 from spreading.

\section{Discussion and conclusions}

A slew of large-scale donkey farms has sprung around China in recent years, contributing considerably to the local economy. However, pandemic illnesses have grown year after year due to the extensive breeding of donkeys [17-19]. Abortions and respiratory illnesses, in particular, have caused significant economic losses for the donkey business in China, severely limiting its expansion. According to previous studies, abortion in donkeys or equids is associated with several microbes, such as Salmonella abortus equ, Leptospira spp, Streptococcus equi ssp, Zooepidemicus, equine arteritis virus (EAV), EHV1, EHV-4, and EHV-8 [4, 14, 20-25]. In a previous study by Li et al., Salmonella abortus equi was reported closely linked with female donkey abortions, although not found in this instance [12]. Furthermore, EHV-1, EHV-4 and EAV were negative in this instance, as in the previous study [12].

EHV-8 has been linked to respiratory symptoms, miscarriages, and neurologic illness in donkeys and horses $[9,10]$. Bacteriology culture and viral screening were conducted in this instance. Only EHV-8 was discovered and isolated, suggesting that EHV-8 is one of the primary pathogenic agents that cause abortion in female donkeys.

Based on our recent study, the positive rate of EHV-8 from large-scale donkey farms in Shandong province might be as high as 25.3 percent. As a result, EHV-8 infection in donkey farms should be given more attention, and suitable preventative measures should be explored to reduce EHV-8 infection. 


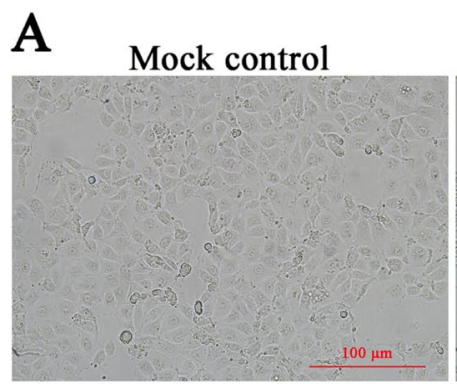

B

\section{DAPI}

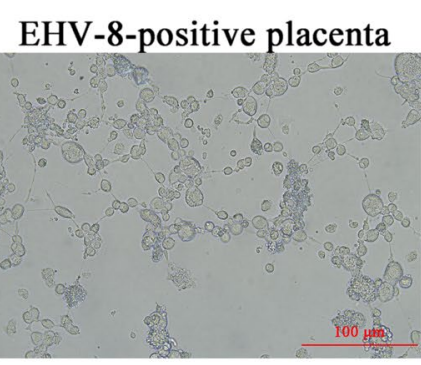

EHV-8 antibody
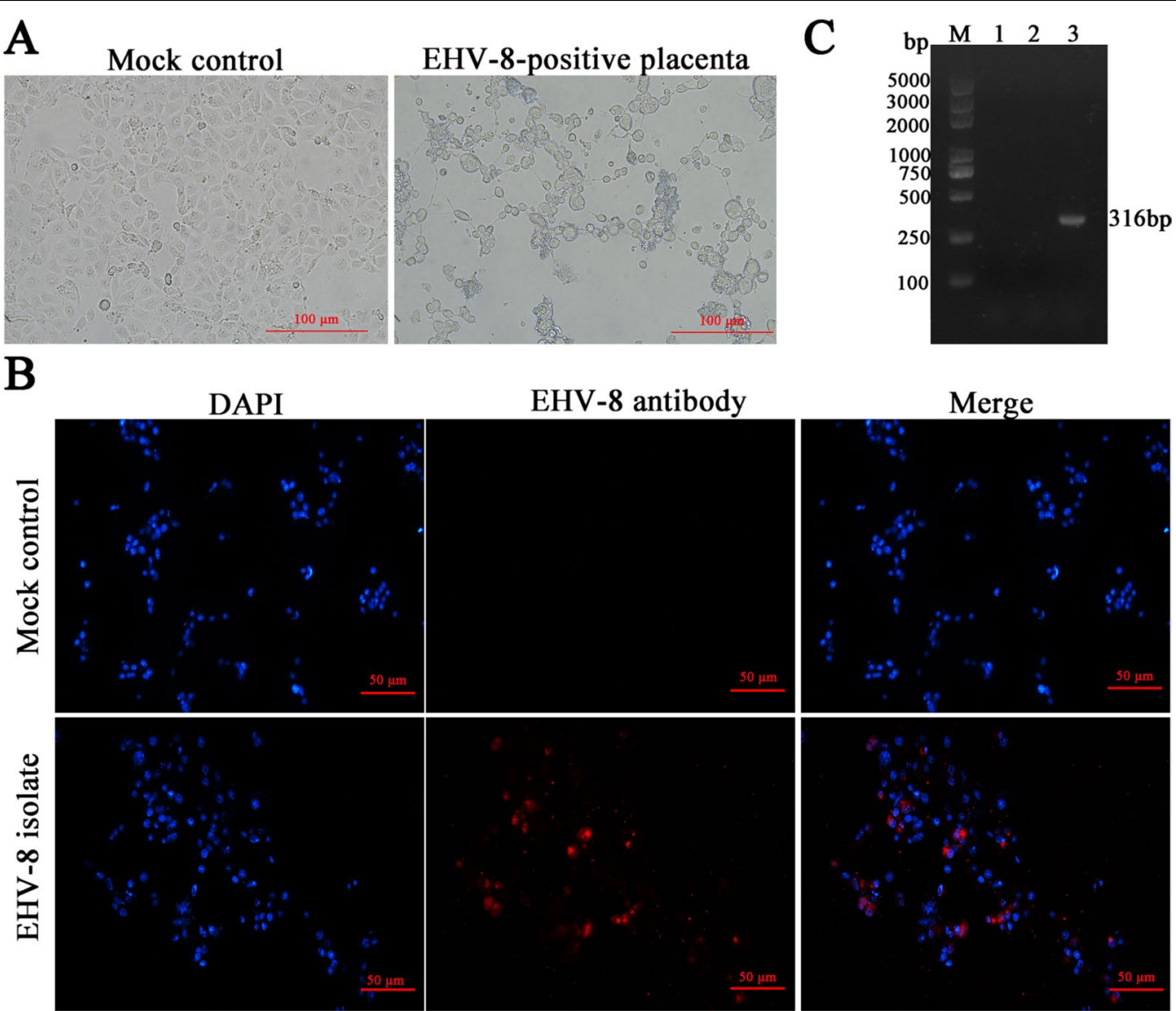

Fig. 4 Isolation and identification of EHV-8. The RK-13 cells were inoculated with supernatant of EHV-8-positive placenta (right panel) or mock control (left panel). a A total of $48 \mathrm{~h}$ post-infection, the CPE was observed using microscopy. Scale bars, $100 \mu \mathrm{m}$. b Identification of EHV-8 isolate by IFA. CPE-positive RK-13 cells and mock control cells were fixed with $75 \%$ alcohol. Images represent the subcellular locations of EHV-8 proteins using indirect immunofluorescence detection using anti-EHV-8 mouse serum, and the corresponding DyLight 594-conjugated secondary antibodies. Cells were imaged by Leica DMi8. Scale bars, $50 \mu \mathrm{m}$. c PCR detection of the EHV-8 ORF70 genes from a different group. The DNA was extracted from these cells. PCR products were electrophoresed in a 1\% agarose gel. Marker (lane M) was included on the left, 1 represents negative control, 2 represents mock control RK-13 cell, 3 represents the CPE positive RK-13 cells

\section{Abbreviations}

EHV-8: Equine herpesvirus-8; EAV: Equine arteritis virus; ORFs: Open reading frames; CPE: Cytopathic effect.

\section{Supplementary Information}

The online version contains supplementary material available at https://doi. org/10.1186/s12985-021-01738-2.

Additional file 1: EHV-8 infection detected from female donkey by PCR.

\section{Acknowledgements}

Not applicable.

\section{Authors' contributions}

T.W. and L.H. performed the research, analyzed the data, and drafted the manuscript. Y.W. and C.W. contributed to the collection of samples and PCR detection. G.L., W.Z., M.Z. contributed to isolating and identifying the virus. W.L. and H.R. revised the manuscript. L.L.conceived the study, carried out additional analyses and finalized the manuscript. All authors contributed to the revising of the manuscript. All authors read and approved the final manuscript.

\section{Funding}

This work was supported by the Scientific Research Fund of Liaocheng University (318051919, 318051918), the Open Project of Shandong Collaborative Innovation Center for Donkey Industry Technology (No. 3193308), the Open Project of Liaocheng University Animal Husbandry Discipline (319312101-23, 319312101-22), and Shandong Province Modern Agricultural Technology System Donkey Industrial Innovation Team (SDAIT-27).

\section{Availability of data and materials}

All relevant data are within this paper.

\section{Declarations}

\section{Ethics approval and consent to participate}

All procedures were approved by the Animal Welfare \& Ethics Committee of the Institute of Animal Science, Liaocheng University (protocol number LC2021-05) and performed according to the Animal Ethics Procedures and 
Guidelines of the Ministry of Agriculture of China. Blood or nasal swabs samples were collected according to the approved procedures. The owner gave informed written consent for their donkey's inclusion in the study. The study was carried out in compliance with the ARRIVE guidelines.

\section{Consent for publication}

The donkey owner provided written consent for publication.

\section{Competing interests}

The authors declare that they have no competing interests.

\section{Author details}

${ }^{1}$ Research Institute of Donkey High-Efficiency Breeding and Ecological Feeding, College of Agronomy, Liaocheng University, Liaocheng, China. ${ }^{2}$ College of Veterinary Medicine, Qingdao Agricultural University, Qingdao, China. ${ }^{3}$ Dairy Cattle Research Center, Shandong Academy of Agricultural Sciences, Ji'nan 250100, China.

Received: 14 November 2021 Accepted: 24 December 2021

Published online: 06 January 2022

\section{References}

1. Zhao J, Negussie H, Laval K, Poelaert KC, Nauwynck HJ. Dual infections of equine herpesvirus 1 and equine arteritis virus in equine respiratory mucosa explants. Virus Res. 2016;220:104-11.

2. Azab W, Kato K, Abdel-Gawad A, Tohya Y, Akashi H. Equine herpesvirus 4: recent advances using BAC technology. Vet Microbiol. 2011;150(1-2):1-14.

3. Browning GF, Ficorilli N, Studdert MJ. Asinine herpesvirus genomes: comparison with those of the equine herpesviruses. Adv Virol. 1988;101(3-4):183-90.

4. Garvey M, Suarez NM, Kerr K, Hector R, Moloney-Quinn L, Arkins S, Davison AJ, Cullinane A. Equid herpesvirus 8: Complete genome sequence and association with abortion in mares. PloS one 2018, 13(2):e0192301.

5. Ficorilli N, Studdert MJ, Crabb BS. The nucleotide sequence of asinine herpesvirus 3 glycoprotein $\mathrm{G}$ indicates that the donkey virus is closely related to equine herpesvirus 1. Adv Virol. 1995;140(9):1653-62.

6. Crabb BS, Studdert MJ. Comparative studies of the proteins of equine herpesviruses 4 and 1 and asinine herpesvirus 3: antibody response of the natural hosts. J Gen Virol. 1990;71 (Pt 9):2033-41.

7. Davison AJ, Eberle R, Ehlers B, Hayward GS, McGeoch DJ, Minson AC, Pellett PE, Roizman B, Studdert MJ, Thiry E. The order Herpesvirales. Adv Virol. 2009;154(1):171-7.

8. Ma G, Azab W, Osterrieder N. Equine herpesviruses type 1 (EHV-1) and 4 (EHV-4)-masters of co-evolution and a constant threat to equids and beyond. Vet Microbiol. 2013;167(1-2):123-34.

9. Liu C, Guo W, Lu G, Xiang W, Wang X. Complete genomic sequence of an equine herpesvirus type $8 \mathrm{Wh}$ strain isolated from China. J Virol. 2012;86(9):5407.

10. Schvartz G, Edery N, Moss L, Hadad R, Steinman A, Karniely S: Equid herpesvirus 8 isolated from an adult donkey in Israel. J Equine Vet Sci 2020, 94:103247.

11. Wang Y, Wu J, Cao Y. The extended spectrum beta-lactamases (ESBL) and virulence genes of intestinal enteroaggregative Escherichia coli (EAEC) in healthy elderly individuals. Int J Clin Exp Med. 2015;8(11):20953-8.

12. Wang H, Liu KJ, Sun YH, Cui LY, Meng X, Jiang GM, Zhao FW, Li JJ. Abortion in donkeys associated with Salmonella abortus equi infection. Equine Vet J. 2019;51(6):756-9.

13. Wang T, Du Q, Wu X, Niu Y, Guan L, Wang Z, Zhao X, Liu SL, Tong D, Huang Y. Porcine MKRN1 modulates the replication and pathogenesis of porcine circovirus Type 2 by inducing capsid protein ubiquitination and degradation. JVirol. 2018;92(11).

14. Ali AA, Refat NA, Algabri NA, Sobh MS. Fetal lesions of EHV-1 in equine. Anais da Academia Brasileira de Ciencias 2020, 92(suppl 2):e20180837.

15. Wang T, Du Q, Niu Y, Zhang X, Wang Z, Wu X, Yang X, Zhao X, Liu SL, Tong $D$ et al. Cellular p32 is a critical regulator of porcine circovirus type 2 nuclear egress. J Virol. 2019;93(23).
16. Bazanow BA, Fracka AB, Jackulak NA, Staroniewicz ZM, Ploch SM. A 34-year retrospective study of equine viral abortion in Poland. Pol J Vet Sci. 2014;17(4):607-12.

17. Yang H, Xiao Y, Meng F, Sun F, Chen M, Cheng Z, Chen Y, Liu S, Chen H. Emergence of H3N8 equine influenza virus in donkeys in China in 2017. Vet Microbiol. 2018;214:1-6.

18. Rui P, Zhao F, Yan S, Wang C, Fu Q, Hao J, Zhou X, Zhong H, Tang M, Hui $W$, et al. Detection of hepatitis E virus genotypes 3 and 4 in donkeys in northern China. Equine Vet J. 2020;52(3):415-9.

19. Dong J, Gao N, Waller AS, Cook FR, Fan S, Yuan D, Du Y, Li F, Norimine J, Zhu W. An outbreak of strangles associated with a novel genotype of Streptococcus equi subspecies equi in donkeys in China during 2018. Equine Vet J. 2019;51 (6):743-8.

20. Marenzoni ML, Lepri E, Casagrande Proietti P, Bietta A, Coletti M, Timoney PJ, Passamonti F. Causes of equine abortion, stillbirth and neonatal death in central Italy. Vet Rec. 2012;170(10):262.

21. Giles RC, Donahue JM, Hong CB, Tuttle PA, Petrites-Murphy MB, Poonacha KB, Roberts AW, Tramontin RR, Smith B, Swerczek TW. Causes of abortion, stillbirth, and perinatal death in horses: 3,527 cases (1986-1991). J Am Vet Med Assoc. 1993;203(8):1170-5.

22. Smith KC, Blunden AS, Whitwell KE, Dunn KA, Wales AD. A survey of equine abortion, stillbirth and neonatal death in the UK from 1988 to 1997. Equine Vet J. 2003;35(5):496-501.

23. Gerst S, Borchers K, Gower SM, Smith KC. Detection of EHV-1 and EHV-4 in placental sections of naturally occurring EHV-1- and EHV-4-related abortions in the UK: use of the placenta in diagnosis. Equine Vet $\mathrm{J}$. 2003;35(5):430-3.

24. Lazic S, Lupulovic D, Gaudaire D, Petrovic T, Lazic G, Hans A. Serological evidence of equine arteritis virus infection and phylogenetic analysis of viral isolates in semen of stallions from Serbia. BMC Vet Res. 2017;13(1):316.

25. Varrasso A, Dynon K, Ficorilli N, Hartley CA, Studdert MJ, Drummer HE. Identification of equine herpesviruses 1 and 4 by polymerase chain reaction. Aust Vet J. 2001;79(8):563-9.

\section{Publisher's Note}

Springer Nature remains neutral with regard to jurisdictional claims in published maps and institutional affiliations.

Ready to submit your research? Choose BMC and benefit from:

- fast, convenient online submission

- thorough peer review by experienced researchers in your field

- rapid publication on acceptance

- support for research data, including large and complex data types

- gold Open Access which fosters wider collaboration and increased citations

- maximum visibility for your research: over $100 \mathrm{M}$ website views per year

At BMC, research is always in progress.

Learn more biomedcentral.com/submissions 